\title{
Modelling the Response of Private Consumption to Income: Evidence from ECOWAS Countries
}

\author{
Yaya KEHO \\ Ecole Nationale Supérieure de Statistique et d'Economie Appliquée (ENSEA) Abidjan, \\ 08 BP 03 Abidjan 08, Côte d'Ivoire \\ Email: yayakeho@yahoo.fr
}

\begin{abstract}
This study investigates the relationship between consumption and income from the Absolute Income Hypothesis perspective for the Economic Community of West African States (ECOWAS). As a modelling strategy, we use the Common Correlated Effect Mean Group (CCEMG) estimator that deals with both slope heterogeneity and cross-sectional dependence. The results show that consumption strongly depends upon current income in all the countries, thereby providing support for the Keynesian theory of consumption. The results also reveal heterogeneity in the elasticity of consumption with respect to income. Therefore, tax reductions may be a good instrument to stimulate household consumption in ECOWAS countries.
\end{abstract}

Keywords: Consumption, GDP, absolute income hypothesis, ECOWAS

JEL Classification: C23, E21, O55

\section{Introduction}

Modelling consumption function has been an area of intensive research in both economics and applied econometrics since the work of Keynes [1]. According to the Keynesian absolute income hypothesis consumption is a positive and a linear function of national income, and as income increases consumption expenditure also increases but less than proportionately. This implies that the marginal propensity to consume is smaller than the average propensity to consume. Keynes did not deny that other variables affect consumption but he argued that current income is the key determinant of current consumption. This relationship was estimated for many countries using various econometric methods. Later, Duesenberrey [2] challenged the Keynesian theory of consumption and introduced the Relative Income Hypothesis. According to this hypothesis, household consumption depends not just on its current income, but on its income relative to those of its group. On the other hand, the Life Cycle Hypothesis due to Modigliani and Brumberg [3] and Ando and Modigliani [4] stipulates that household consumption depends in part on current income, but also on lifetime expected income and wealth. Similarly, the Permanent Income Hypothesis (PIH) advocated by Friedman [5] showed that consumption is determined by permanent income rather than transitory or relative income. Permanent income represents the stable income which households expect to persist into the future while transitory income represents the difference between the short term current income and the permanent income. According to the Permanent Income Hypothesis, only changes in permanent income can alter consumption. Hall [6] introduced rational expectations into the life cycle and permanent income hypotheses and argued that current consumption is adequate to determine future consumption, disposable income, both current and past, have no effect on future consumption.

The study of consumption behavior plays a central role in economics. First, consumption determines saving defined as the portion of income not consumed. It follows that the consumption behavior has an impact on the long term economic growth. Second, since consumption expenditure represents a major component of gross domestic output, understanding how consumers respond to income shocks is essential for evaluating the macroeconomic impact of tax and labor market reforms.

A number of empirical studies estimated consumption functions for individual countries and groups of countries. For instance, Khan and Mohammed [7] and Mallik and Pradhan [8] obtained evidence supporting the absolute income hypothesis in Pakistan and India, respectively. Saad [9] confirmed the leading role of income and wealth in private consumption in the case of Lebanon. Ibrahim [10] and 
Algaeed [11] reported that income has a positive effect on private consumption in Saudi Arabia. Verter and Osakwe [12] also found that disposable income impacts significantly on household spending in the Czech Republic. Bedir and Kantar [13] confirmed the validity of the Keynesian Absolute Income Hypothesis for $16 \mathrm{EU}$ and 26 OECD countries. According to Nikbin and Panahi [14], private consumption is positively related to GDP in Iran. Lunfang et al. [15] rejected the permanent income hypothesis in favor of the absolute income hypothesis for China. In the African context, Kweka and Morrissey [16] found no evidence of impact of growth of GDP on consumption expenditure in Tanzania. In the case of Cameroon, Forgha [17] found that disposable income impacted positively on private consumption. The results obtained by Chioma [18] suggested that an increase in income has no significant effect on private consumption in Nigeria. This finding has been challenged by Akekere and Yousuo [19], Odionye et al. [20] and Ezeji and Ajudua [21] who reported a positive and significant impact of income on private consumption. Ofwona [22] also validated the absolute income hypothesis for Kenya. Bonsu and Muzindutsi [23] showed that income has a long-run positive effect on household consumption in Ghana. Sekantsi [24] and Damane [25] investigated the case of Lesotho and found that higher income is associated with higher private consumption.

Despite the literature on the test of the absolute income hypothesis, there exists a paucity of empirical studies on this subject for West African countries. This study investigates the relationship between consumption and income for 12 ECOWAS countries. As a modeling strategy, we employ the Common Correlated Effects Mean Group (CCEMG) estimator developed by Pesaran [26] that accounts for both slope heterogeneity and cross-section dependence.

The remainder of the paper is organized as follows. Section 2 describes the empirical model and data. Section 3 outlines the modelling strategy employed for the empirical analysis. Section 4 reports and discusses the empirical results of the study. Finally, Section 5 concludes the study and provides some policy recommendations.

\section{Empirical Model and Data}

The objective of this work is to estimate the relationship between consumption and income. To do so, we specify a typical linear panel consumption equation as follows:

$$
\log C_{i t}=\alpha_{i}+\beta_{i} \log Y_{i t}+\mu_{i t}
$$

where $C_{i t}$ is real private consumption and $Y_{i t}$ is real income of country $i$ in year $t$. The coefficient on income is expected to be positive and lower than one. It is allowed to be heterogeneous across countries.

Table 1. Descriptive statistics of the variables

\begin{tabular}{|c|c|c|c|c|c|c|c|c|}
\hline \multirow{2}{*}{ Country } & \multicolumn{4}{|c|}{ Consumption } & \multicolumn{4}{|l|}{ GDP } \\
\hline & Mean & Max. & Min. & St. dev & Mean & Max. & Min. & St. dev \\
\hline Benin & 21.798 & 22.567 & 21.121 & 0.434 & 22.013 & 22.931 & 21.234 & 0.524 \\
\hline Burkina Faso & 21.768 & 22.715 & 20.972 & 0.544 & 22.080 & 23.239 & 21.153 & 0.637 \\
\hline Cote d'Ivoire & 23.233 & 23.895 & 22.457 & 0.326 & 23.676 & 24.328 & 23.014 & 0.278 \\
\hline Gambia & 19.921 & 20.716 & 18.885 & 0.523 & 20.165 & 20.804 & 19.509 & 0.390 \\
\hline Ghana & 23.247 & 24.163 & 22.641 & 0.484 & 23.482 & 24.597 & 22.844 & 0.538 \\
\hline Guinea Bissau & 20.070 & 20.585 & 19.401 & 0.355 & 20.213 & 20.779 & 19.626 & 0.318 \\
\hline Mali & 22.147 & 23.132 & 21.241 & 0.481 & 22.338 & 23.320 & 21.486 & 0.552 \\
\hline Niger & 21.761 & 22.424 & 21.377 & 0.274 & 22.014 & 22.813 & 21.543 & 0.336 \\
\hline Nigeria & 25.592 & 26.623 & 24.884 & 0.552 & 25.970 & 26.863 & 25.342 & 0.507 \\
\hline Senegal & 22.449 & 23.248 & 21.727 & 0.452 & 22.731 & 23.546 & 22.153 & 0.408 \\
\hline Sierra Leone & 21.151 & 22.136 & 20.608 & 0.366 & 21.307 & 22.106 & 20.976 & 0.299 \\
\hline Togo & 21.183 & 21.980 & 19.958 & 0.510 & 21.497 & 22.169 & 20.926 & 0.326 \\
\hline Panel & 21.982 & 26.623 & 18.885 & 1.450 & 22.244 & 26.863 & 19.509 & 1.498 \\
\hline
\end{tabular}

We use annual data on real household final consumption expenditure and real gross domestic product (GDP) for 12 ECOWAS countries including: Benin, Burkina Faso, Cote d'Ivoire, Gambia, Ghana, 
Guinea Bissau, Mali, Niger, Nigeria, Senegal, Sierra Leone, and Togo. Both variables are measured in constant 2010 US dollar and then expressed in logarithmic form. The data cover the period 1970-2016, except for Gambia (1977-2016) and Nigeria (1981-2016). All data series were obtained from the 2018 World Development Indicators of the World Bank. Table 1 presents the descriptive statistics for each country and the panel as a whole. This Table shows heterogeneity across countries. The average consumption expenditure (in log) ranges from 20.07 in Guinea Bissau to 25.592 in Nigeria. Similarly, the average GDP (in log) varies from 20.165 in Gambia to 25.970 in Nigeria.

\section{Econometric Methodology}

Before estimating the consumption function, three econometric key issues need to be addressed. The first issue is to test for cross-sectional dependence in the variables. In presence of cross-sectional correlation, standard panel estimation methods produce inconsistent estimates (Breusch and Pagan, [27]; Pesaran [28]; Eberhardt and Teal [29]; Kapetanios et al. [30]; Sarafidis and Wansbeek [31]. The second important issue to test is whether or not the slope coefficients are homogeneous among panel members. The third issue is related to the presence of a meaningful long-run relationship between consumption and GDP.

\subsection{Testing for Cross-sectional Dependence}

To test for cross-sectional dependence in panel data, the econometric literature proposes various tests. In Eq.(1), the null hypothesis of no cross-sectional dependence is $\mathrm{H}_{0}$ : $\operatorname{cov}\left(u_{i t}, u_{j t}\right)=0$ for all $t$ and $i \neq j$. Initially, Breusch and Pagan [27] proposed the following Lagrange Multiplier (LM) statistic:

$$
C D_{L M}=T \sum_{i=1}^{N-1} \sum_{j=i+1}^{N} \hat{\rho}_{i j}^{2}
$$

where $\hat{\rho}_{i j}$ is the sample correlation coefficient among the residuals obtained from individual OLS estimations of Eq.(1). Under the null hypothesis of no cross-sectional dependence, the $L M$ statistic is asymptotically distributed as Chi-square with $N(N-1) / 2$ degrees of freedom. In the case of an unbalanced panel, only completed observations are included, i.e. $T_{i j}=\min \left(T_{i}, T_{j}\right)$, where $T_{i}$ is the number of observations for individual $i$.

Pesaran [28] proposed the scaled version of the $L M$ statistic, which is defined for balanced panels as follows:

$$
L M_{S}=\sqrt{\frac{1}{N(N-1)}}\left(\sum_{i=1}^{N-1} \sum_{j=i+1}^{N}\left(T \hat{\rho}_{i j}^{2}-1\right)\right)
$$

This statistic is asymptotically distributed as standard normal. To address the size distortion of $L M$ and $L M S$, Pesaran [28] also proposed a more general cross-sectional dependency test that is defined as follows:

$$
C D_{P}=\sqrt{\frac{2 T}{N(N-1)}}\left(\sum_{i=1}^{N-1} \sum_{j=i+1}^{N} \hat{\rho}_{i j}\right)
$$

In the case of an unbalanced panel, the $C D$ test statistic becomes:

$$
C D=\sqrt{\frac{2}{N(N-1)}}\left(\sum_{i=1}^{N-1} \sum_{j=i+1}^{N} \sqrt{T_{i j}} \hat{\rho}_{i j}\right)
$$

Under the null hypothesis of no cross-sectional dependence, the $C D$ test statistic is asymptotically distributed as standard normal.

Table 2 reports the results of the tests for cross-sectional dependence in the variables and the residuals. The results indicate that the null hypothesis of no cross-sectional dependence across the members of panel is strongly rejected. This suggests that there are cross-section connections among ECOWAS countries, and that a shock to one of them is likely to affect the others. 
Table 2. Results for cross-sectional dependence tests

\begin{tabular}{|c|c|c|c|c|c|c|}
\hline \multirow{2}{*}{ Variables } & \multicolumn{2}{|c|}{ Breusch-Pagan LM } & \multicolumn{2}{|c|}{ Pesaran scaled LM } & \multicolumn{2}{|c|}{ Pesaran CD } \\
\hline & Test stat. & Prob. & Test stat. & Prob. & Test stat. & Prob. \\
\hline LCONS & $2405.049^{*}$ & 0.000 & $203.588^{*}$ & 0.000 & $48.850^{*}$ & 0.000 \\
\hline LGDP & $2452.981^{*}$ & 0.000 & $207.760^{*}$ & 0.000 & $49.283^{*}$ & 0.000 \\
\hline Residuals & $674.026^{*}$ & 0.000 & $52.921^{*}$ & 0.000 & $5.015^{*}$ & 0.000 \\
\hline
\end{tabular}

Note: LCONS is the log of real private final consumption, LGDP is the log of real gross domestic product. ${ }^{*}$ indicates rejection of the null hypothesis at the $5 \%$ significance level.

\subsection{Testing for Slope Homogeneity}

In most standard panel data estimation methods, the slope coefficients are assumed to be identical across countries. If this assumption does not hold, these methods will produce inaccurate results (Pesaran and Smith, [32]; Pesaran et al. [33]). Even though ECOWAS countries belong to the same geographic area, they are not identical in terms of economic development.

The standard F-test is widely used to test the null hypothesis of slope homogeneity $\mathrm{H}_{0}$ : $\beta_{i}=\beta$ for all $i$ against the alternative of heterogeneity $\mathrm{H}_{1}: \beta_{i} \neq \beta_{j}$ for a non-zero fraction of pair-wise slopes. However, the F-test requires that the explanatory variables are strictly exogenous, and the error variances are homoscedastic. Swamy [34] proposed a slope homogeneity test that relaxes the assumption of homoscedasticity allowing for group-wise heteroscedasticity. This test is based on the following statistic:

$$
\tilde{S}=\sum_{i=1}^{N}\left(\hat{\beta}_{i}-\hat{\beta}_{W F E}\right)^{\prime} \frac{x_{i}^{\prime} M_{\tau} x_{i}}{\tilde{\sigma}_{i}^{2}}\left(\hat{\beta}_{i}-\hat{\beta}_{W F E}\right)
$$

where $\hat{\beta}_{i}$ is the pooled OLS estimator, $\hat{\beta}_{W F E}$ is the weighted fixed effect pooled estimator, $M_{\tau}$ is an identity matrix, and $\tilde{\sigma}_{i}^{2}$ is the estimator of $\sigma_{i}^{2}$. Under the null hypothesis of slope homogeneity, this statistic is asymptotically distributed as Chi-square with $k(N-1)$ degrees of freedom when $N$ is fixed and $T \rightarrow \infty$. Pesaran and Yamagata [35] stated that both the $F$ and Swamy tests require data where $N$ is relatively small compared to $T$. To overcome this problem they proposed a standardized version of Swamy's test defined as follows:

$$
\tilde{\Delta}=\sqrt{N}\left(\frac{N^{-1} \tilde{S}-k}{\sqrt{2 k}}\right)
$$

The small sample properties of the delta test can be improved by using the following mean and variance bias adjusted version:

$$
\tilde{\Delta}_{a d j}=\sqrt{N}\left(\frac{N^{-1} \tilde{S}-E\left(\tilde{z}_{i t}\right)}{\sqrt{\operatorname{var}\left(\tilde{z}_{i t}\right)}}\right)
$$

where $E\left(\tilde{z}_{i t}\right)=k, \operatorname{var}\left(\tilde{z}_{i t}\right)=2 k(T-k-1) /(T+1)$.

Under the null hypothesis, the delta test and its adjusted version have an asymptotic standard normal distribution.

Table 3. Results of homogeneity tests

\begin{tabular}{lll}
\hline Test & Statistic & Prob. \\
\hline Roy-Zellner & $142.90^{*}$ & 0.000 \\
Swamy test & $685.59^{*}$ & 0.000 \\
Delta & $95.492^{*}$ & 0.000 \\
Delta adjusted & $99.885^{*}$ & 0.000 \\
\hline Note: $*$ indicates rejection of the null hypothesis of slope homogeneity at the $5 \%$ \\
significance level.
\end{tabular}

Table 3 presents the results of slope homogeneity tests of the relationship between consumption and income. In addition to the Pesaran and Yamagata [35] delta tests and the Swamy [34] test, we perform 
the Roy-Zellner test which is a generalization of the standard Chow test. The results support the alternative hypothesis that heterogeneity exists in the consumption-income nexus among ECOWAS countries.

\subsection{Estimation Method}

To deal with both cross-section dependence and parameter heterogeneity, we employ the Common Correlated Effects Mean Group (CCEMG) estimator designed by Pesaran [26]. This method has been shown to be robust to omitted variables bias and endogeneity of regressors. The CCEMG estimator assumes the following multifactor error structure:

$$
\begin{gathered}
\log Y_{i t}=\phi_{i} f_{t}+\varphi_{i}+\eta_{i t} \\
\mu_{i t}=\omega_{i} f_{t}+e_{i t}
\end{gathered}
$$

where $\varphi_{i}$ is an individual effect, $f_{t}$ is a mx1 vector of unobserved common effects with country-specific factor loadings $\phi_{i}$ and $\eta_{i t}$ are individual country-specific idiosyncratic errors assumed to be distributed independently of the common factors and across $i$. In Eq.(10) $\omega_{i}$ is a mx1 loading vector capturing the country-specific effect of the common factor $f_{t}$, and $e_{i t}$ are idiosyncratic errors assumed to be distributed independently of $\log Y_{i t}$ and $f_{t}$. The error term, $\mu_{i t}$, is allowed to be correlated with income through the presence of the factors $f_{t}$ in both.

The CCEMG estimator eliminates unobserved common factors by using simple cross-section averages of the dependent and independent variables as additional regressors:

$$
\log C_{i t}=\alpha_{i}+\beta_{i} \log Y_{i t}+c_{i} \overline{\log C}_{t}+d_{i} \overline{\log Y}_{t}+e_{i t}
$$

The consistent estimate of the parameter $\beta$ is obtained as simple average of the group-specific estimates.

To know if we can refer to Eq.(1) as a long run relationship, we test for unit root in the residuals obtained from the CCEMG estimator. To this end, we apply the Cross-sectionally Augmented DickeyFuller (CADF) panel unit root test proposed by Pesaran [36], which takes into account both slope heterogeneity and cross-section dependence. This test follows the Common Correlated Effects approach by augmenting the ADF regressions with cross section averages.

\section{Empirical Results and Discussion}

We begin the empirical analysis by checking the time-series properties of the variables by means of unit root tests. We first apply the well-known IPS test developed by Im et al. [37], which is less restrictive and more powerful compared to the other first generation panel unit root tests. The IPS test allows heterogeneity in the autoregressive coefficient. However, this test assumes that the errors are independent across countries. Given the above results, we employ the Cross-sectional Augmented Dickey-Fuller (CADF) test proposed by Pesaran [36]. The results of these tests reported in Table 4 indicate that the null hypothesis of unit root cannot be rejected for both variables. However, when applied to the first differences of the variables, the null hypothesis of unit root is clearly rejected. Thus, we can regard the variables as being integrated of order one, which suggests that there might be a longrun relationship among them.

Table 4. Panel unit root test results

\begin{tabular}{llllll}
\hline \multirow{2}{*}{ Series } & No trend & & & With trend & \\
\cline { 2 - 3 } \cline { 5 - 6 } & IPS test & CADF test & & IPS test & CADF test \\
\hline LCONS & $6.334(1.000)$ & $0.264(0.604)$ & & $-0.883(0.188)$ & $2.501(0.994)$ \\
LGDP & $8.580(1.000)$ & $1.007(0.843)$ & & $-0.361(0.358)$ & $2.739(0.997)$ \\
$\triangle$ LCONS & $-19.304^{*}(0.000)$ & $-8.443^{*}(0.000)$ & & $-14.431^{*}(0.000)$ & $-6.913^{*}(0.000)$ \\
$\triangle$ LGDP & $-18.006^{*}(0.000)$ & $-6.895^{*}(0.000)$ & & $-14.453^{*}(0.000)$ & $-5.071^{*}(0.000)$ \\
\hline
\end{tabular}

Notes: The IPS test provides W-t-bar statistic, whereas the CADF test provides z-t-bar statistic of Pesaran's CADF test. p-values are given in parentheses. Optimal lag length was determined using AIC with a maximum of $5 .\left(^{*}\right)$ denotes rejection of the null hypothesis of unit root at the $5 \%$ significant level. 
The existence of cross-sectional dependency and slope heterogeneity among countries make the CCEMG estimator suitable for estimating the long and short run relationships between consumption and income. The long and short run coefficients are derived from averaging the coefficient estimates from individual time-series regressions. The results are presented in Table 5. For each regression we test the residuals for stationarity using heterogeneous panel unit root tests. The CADF and IPS test results displayed at the bottom of the Table suggest rejection of the null hypothesis of unit root in the residual series. Therefore, we can conclude that there exists a long run relationship between consumption and income over the period under study. Owing to this fact, we proceed with the analysis of the long and short run estimates. The results show a strong and significant relationship between household consumption and current income. The long-term elasticity of household consumption with respect to current income is about 0.93 for the panel. This means that a $1 \%$ increase in income results in a $0.93 \%$ increase in private consumption expenditure. The fact that the elasticity is lower than one implies that as income increases the average consumption propensity decreases. This finding is consistent with the absolute income hypothesis advocated by Keynes [1], and indicates that private consumption strongly depends on current income. The individual country estimates show considerable heterogeneity in the relationship between consumption and income. The long run elasticity ranges from 0.512 in Mali to 1.992 in Gambia. All the coefficients are positive and statistically significant at the $5 \%$ level of significance.

We look at the short run estimates. The short run elasticity is highly statistically significant with a value of 0.691 for the panel, implying that in the short-run an increase of $1 \%$ in the current income would increase current consumption by $0.691 \%$. This result confirms the strong dependency of current consumption to current income. The short run elasticity coefficient ranges from 0.105 in Mali to 1.043 in Sierra Leone. The point estimate of the error correction term is negative and significant for the panel and individual countries. This provides evidence in support of the existence of a long-run relationship between consumption and income, and also suggests that income Granger-causes consumption expenditure in the long run. Thus even at the individual country level there is evidence supporting the absolute income hypothesis.

Table 5. CCEMG long and short run estimation results

\begin{tabular}{|c|c|c|c|c|c|c|}
\hline \multirow{3}{*}{ Countries } & \multirow{2}{*}{\multicolumn{2}{|c|}{$\begin{array}{l}\text { Long-run estimates } \\
\text { logGDP }\end{array}$}} & \multicolumn{4}{|c|}{ Short-run estimates } \\
\hline & & & \multicolumn{2}{|c|}{$\triangle \log G D P$} & \multicolumn{2}{|l|}{$\mathrm{ECM}_{\mathrm{it}-1}$} \\
\hline & Coef. & t-stat. & Coef. & t-stat. & Coef. & t-stat. \\
\hline Benin & $0.871^{*}$ & 8.22 & $0.730^{*}$ & 3.45 & $-0.523^{*}$ & -3.69 \\
\hline Burkina Faso & $1.104^{*}$ & 10.46 & $0.929^{*}$ & 3.51 & $-0.362^{*}$ & -3.49 \\
\hline Cote d'Ivoire & $0.869^{*}$ & 12.69 & $0.893^{*}$ & 5.79 & $-0.341^{*}$ & -2.92 \\
\hline Gambia & $1.992^{*}$ & 7.04 & 0.341 & 0.54 & $-0.469^{*}$ & -2.72 \\
\hline Ghana & $0.759^{*}$ & 12.56 & $0.832^{*}$ & 4.70 & $-0.591^{*}$ & -4.26 \\
\hline Guinea Bissau & $1.144^{*}$ & 11.30 & $0.862^{*}$ & 6.94 & $-0.701^{*}$ & -5.20 \\
\hline Mali & $0.512^{*}$ & 3.42 & 0.105 & 0.41 & $-0.291^{*}$ & -2.70 \\
\hline Niger & $0.678^{*}$ & 9.26 & $0.556^{*}$ & 3.78 & $-0.645^{*}$ & -4.02 \\
\hline Nigeria & $0.718^{*}$ & 4.98 & $0.507^{* *}$ & 1.77 & $-1.012^{*}$ & -5.44 \\
\hline Senegal & $0.761^{*}$ & 8.85 & $0.572^{*}$ & 5.28 & $-0.419^{*}$ & -4.07 \\
\hline Sierra Leone & $1.004^{*}$ & 12.57 & $1.043^{*}$ & 7.32 & $-0.563^{*}$ & -4.19 \\
\hline Togo & $0.743^{*}$ & 4.46 & $0.923^{*}$ & 3.64 & $-1.121^{*}$ & -7.64 \\
\hline Panel & $0.930^{*}$ & 8.47 & $0.691^{*}$ & 8.58 & $-0.587^{*}$ & -7.91 \\
\hline \multicolumn{7}{|l|}{ Unit root tests } \\
\hline IPS & \multicolumn{2}{|c|}{$-9.743^{*}(0.000)$} & \multicolumn{4}{|c|}{$-14.699^{*}(0.000)$} \\
\hline $\mathrm{CADF}$ & \multicolumn{2}{|c|}{$-5.097^{*}(0.000)$} & \multicolumn{4}{|c|}{$-5.526^{*}(0.000)$} \\
\hline
\end{tabular}

Note: CCEMG is the Common Correlated Effects Mean Group by Pesaran [26]. IPS unit root test provides W-t-bar statistic, whereas the CADF test provides z-t-bar statistic with $p$-values in parentheses. Optimal lag length was determined using AIC with a maximum of 5. IPS and CADF tests are conducted in the case of an intercept only. ${ }^{*}$ and ${ }^{* *}$ indicate significance at the $5 \%$ and $10 \%$ levels, respectively. 


\section{Conclusion and Recommendations}

In this study, the relationship between private consumption and income was examined for 12 ECOWAS countries over the period from 1970 to 2016. Contrary to previous panel studies which are typically based on standard panel estimators, we have made use of a more efficient panel estimation framework which controls for both parameter heterogeneity and cross-section dependence among the panel groups. Our empirical strategy deals with these issues using the Common Correlated Effects Mean Group estimator developed by Pesaran [26]. The results strongly support the hypothesis that consumption is strongly and positively associated with current income both in the short and long run. The long-term elasticity of consumption with respect to income was found 0.93 for the panel and varies between 0.512 and 1.992. The short term elasticity was about 0.691 for the whole panel and varies between 0.105 and 1.043. As a result, we can conclude that the Keynesian absolute income hypothesis is valid in ECOWAS countries. From a policy perspective, this finding suggests that tax policy aimed at reducing income taxes will increase household consumption in ECOWAS countries.

\section{References}

1. J. M. Keynes, The General Theory of Employment, Interest and Money. Macmillan London Press, 1936.

2. J. S. Duesenberry, Income, Saving, and the Theory of Consumer Behavior. Cambridge, Harvard University Press, 1949.

3. F.Modigliani, and R. H. Brumbreg, "The life cycle hypothesis of saving: aggregate implication and tests", American Economic Review, vol. 53, pp. 55-84, 1954.

4. A. Ando, and F. Modigliani, "The life-cycle hypothesis of saving: aggregate implications and tests", American Economic Review, vol. 53, pp. 55-84, 1963.

5. M. Friedman, A Theory of Consumption Function. Princeton, NJ: Princeton University Press, 1957.

6. R, E. Hall, "Stochastic implications of the life cycle permanent income hypothesis: theory and evidence, Journal of Political Economy, vol. 86, pp. 971-987, 1978.

7. K. Khan and N. Mohammed, "Permanent income hypothesis, myopia and liquidity constraints: a case study of Pakistan", Pakistan Journal of Social Sciences (PJSS), vol. 31, no. 2, pp. 299-307, 2011.

8. L. Mallik and K.C. Pradhan, "Per capita consumption expenditure and personal disposal income in India - an econometric analysis", International Journal of Economics and Research, vol. 3, no. 2, pp. 96-102, 2012.

9. W. Saad, "An econometric study of the private consumption function in Lebanon", International Research Journal of Finance and Economics, vol. 61, pp. 29-41, 2011.

10. M. A. Ibrahim, "The private consumption function in Saudi Arabia", American Journal of Business Management, vol. 3, no. 2, pp. 109-116, 2014.

11.A. H. Algaeed, "Money supply as a conduit of the consumption in the Saudi economy: a cointegration approach", International Journal of Economics, Finance and Management Sciences, vol. 4, no. 5, pp. 269-274, 2016.

12. N. Verter and C. N. Osakwe, "A time series analysis of macroeconomic determinants of household spending in the era of cross-cultural dynamics: Czech Republic as a case study", Procedia Economics and Finance, vol. 12, pp. $733-742,2014$.

13.S. Bedir and M. Kantar, "Cointegration analysis of income consumption relationship of EU and OECD countries: a panel data analysis approach", International Journal of Economics, Commerce and Management, vol. 4, no. 4, $1-25,2016$.

14. B. Nikbin and S. Panahi, "Estimation of private consumption function of Iran: autoregressive distributed lag approach to co-integration", International Journal of Economics and Financial Issues, vol. 6, no. 2, pp. 653-659, 2016.

15. D. Lunfang, K. Khan., I. Khan, and N. H. Khan, "Testing the empirical validity of permanent income hypothesis and absolute income hypothesis for China", The Empirical Economics Letters, vol. 17, no. 4, pp. 453-460, 2018.

16. C. Kweka and O. Morrissey, "Impacts of economic growth on consumption expenditures", Tanzanian Economic Journal, vol. 15, pp. 1-34, 1998.

17. N. G. Forgha, "Econometric models of consumption and savings functions in Cameroon: an error correction methodology", International Review of Business Research Papers, vol. 4, no. 3, pp. 291-308, 2008. 
18. N. J. Chioma, "Causal relationship between gross domestic product and personal consumption expenditure of Nigeria", African Journal of Mathematics and Computer Science Research, vol. 2, no. 8, pp. 179-183, 2009.

19. J. Akekere and P. O. J. Yousuo, "Empirical analysis of change in income on private consumption expenditure in Nigeria from 1981- 2010", International Journal of Academic Research in Business and Social Sciences, vol. 2, no. 12 , pp.188-197, 2012.

20. C. J. Odionye, S. U. Ugwuebe and S. O. Ibeleme, "The effect of financial wealth on private consumption: evidence from Nigeria", British Journal of Economics, Management $\mathscr{6}$ Trade, vol. 6, no. 4, pp. 300-307, 2015.

21. C. E. Ezeji and E. I. Ajudua, "Determinants of aggregate consumption expenditure in Nigeria", Journal of Economics and Sustainable Development, vol. 6, no. 5, pp. 164-169, 2015.

22. A. C. Ofwona, "An estimation of the consumption function for Kenya using Keynes' absolute income hypothesis for the period 1992-2011", Journal of Emerging Trends in Economics and Management Sciences, vol. 4, no. 1, pp. 103-105, 2013.

23. C. O. Bonsu and P.-F. Muzindutsi, "Macroeconomic determinants of household consumption expenditure in Ghana: a multivariate cointegration approach", International Journal of Economics and Financial Issues, vol. 7, no. 4, pp. 737-745, 2017.

24. L. P. Sekantsi, "Determinants of real private consumption expenditure in Lesotho", European Journal of Economics and Management, vol. 3, no. 2, pp. 72-89, 2016.

25. M. Damane, "Empirical Analysis of Private Consumption in Lesotho: An ARDL Bound Test Approach", Modern Economy, vol. 9, no. 3, pp. 400-421, 2018.

26. M. H. Pesaran, "Estimation and inference in large heterogeneous panels with a multifactor error structure", Econometrica, vol. 74, no. 4, pp. 967-1012, 2006.

27. T. S. Breusch and A. R. Pagan, "The Lagrange multiplier test and its application to model specification in econometrics", Review of Economic Studies, vol. 47, no. 1, pp. 239-253, 1980.

28.M. H. Pesaran, General diagnostic tests for cross section dependence in panels. CESifo Working Paper Series No. 1229; IZA Discussion Paper No. 1240, 2004.

29. M. Eberhardt and F. Teal, "Econometrics for grumblers: a new look at the literature on cross-country growth empirics", Journal of Economic Surveys, vol. 25, no. 1, pp. 109-155, 2011.

30. G. Kapetanios, M. Pesaran, and T. Yamagata, "Panels with non-stationary multifactor error structures", Journal of Econometrics, vol. 160, no. 2, pp. 326-348, 2011.

31. V. Sarafidis and T. Wansbeek, "Cross-sectional dependence in panel data analysis", Econometric Reviews, vol. 31, no. 5, pp. 483-531, 2012.

32. M. H. Pesaran and R. P. Smith, "Estimating long-run relationship from dynamic heterogeneous panels", Journal of Econometrics, vol. 68, no.1, pp.79-113, 1995.

33. M. H. Pesaran, Y. Shin and R. P. Smith, "Pooled mean group estimation of dynamic heterogeneous panels", Journal of the American Statistical Association, vol. 94, no. 446, pp. 621-634, 1999.

34. P. Swamy "Efficient inference in a random coefficient regression model", Econometrica, vol. 38, no. 2, pp. 311323, pp. 1970.

35.M. H. Pesaran and T. Yamagata, "Testing slope homogeneity in large panels", Journal of Econometrics, vol. 142, no. 1, pp. 50-93, 2008.

36. Pesaran, M. H., "A simple panel unit root test in the presence of cross-section dependence", Journal of Applied Econometrics, vol. 22, no. 2, pp. 265-312, 2007.

37. K. S. Im, M. H. Peseran and Y. Shin, "Testing for Unit Roots in Heterogeneous Panels", Journal of Econometrics, vol. 115, no. 1, pp. 53-74, 2003. 